\title{
An Analysis of Potential Structural Change in the Demand for South Atlantic Fresh Peaches
}

\author{
J.E. Epperson, M.C. Chien, and W.O. Mizelle, Jr. \\ Department of Agricultural and Applied Economics, University of \\ Georgia, Athens, GA 30602
}

Additional index words. Prunus persica, recursive regression, marketing, economics

\begin{abstract}
An analysis was conducted using time-series data to identify possible structural change in the farm-gate demand for South Atlantic fresh peaches [Prunus persica (L.) Batsch.]. Structural change was not found in the price-quantity relationship. However, a failing per capita consumption of South Atlantic fresh peaches was found to be associated with an increase in the per capita consumption of fresh fruits in general. Thus, measures such as promotion and advertising, uniform quality control, and cultivar development may increase the demand for South Atlantic fresh peaches.
\end{abstract}

Recently, concerns have surfaced among South Atlantic peach growers regarding an apparent lack of growth in the farm-gate demand for peaches in the United States. More specifically, concerns are that structural changes (changes in demand relationships) have occurred in the market for fresh peaches in the United States (McCurry, 1984; Mizelle, 1984).

Since the mid-1970s, health and nutrition have generally played a much larger role in food purchase decisions. As a result, the per capita consumption of fresh fruits and vegetables has continued to rise (Epperson, 1986; Putnam, 1989). According to a national survey of households in the United States, nutrition and health maintenance are the leading reasons 'for increased produce consumption (Zind, 1991).

However, in the face of a rising per capita consumption for fresh fruits, per capita consumption of fresh peaches has declined from $2.63 \mathrm{~kg}$ in 1966 to $2.04 \mathrm{~kg}$ in 1986 (Putnam, 1989). In contrast, during the same period, per capita consumption of apples (Malus domesticu Borkh.) rose from 6.98 to $9.21 \mathrm{~kg}$, grapes (Vitis spp.) from 1.77 to $2.95 \mathrm{~kg}$, nectarines from 0.27 to $0.64 \mathrm{~kg}$, pears ( $P y$ rus communis L.) from 1.04 to $1.45 \mathrm{~kg}$, and plums and prunes (Prunus spp.) from 0.50 to $0.86 \mathrm{~kg}$ (Putnam, 1989).

Received for publication 9 Aug. 1991. Accepted for publication 19 May 1992. The cost of publishing this paper was defrayed in part by the payment of page charges. Under postal regulations, this paper therefore must be hereby marked $a d$ vertisement solely to indicate this fact.
We investigated possible structural change in farm-gate demand for fresh peaches produced in the South Atlantic region. Structural change occurs if one or more of the coefficients, including the intercept, in the demand relationship change over time. Structural change may be caused by changes in tastes and preferences, changes in the distribution of wealth, and the introduction of new products (Tomek and Robinson, 1981).

The South Atlantic region, which accounted for $36 \%$ of the fresh peaches produced in the United States in 1986, encompasses Delaware, Maryland, Virginia, West Virginia, North Carolina, South Carolina, and Georgia (U.S. Dept. of Agriculture, 1943-87). The shipping season for the South Atlantic region extends from May to September, while for California, the chief alternative source of supply, the season extends from May to October. Imports during this period are few. Shipments of South Atlantic fresh peaches are largely to markets east of the Mississippi River (U.S. Dept. of Agriculture, Agricultural Marketing Service, 1985-89).

The following inverse demand relationship was specified for fresh South Atlantic peaches:

$$
P_{S_{A}}=f\left(Q_{S A}, P_{C A}, P_{P}, I\right)
$$

where $\mathrm{P}_{\mathrm{SA}}$ is the deflated (Consumer Price Index, 1982-84 = 100) free on board (F.O.B.) price of fresh peaches produced in the South Atlantic region, $\mathrm{Q}_{\mathrm{SA}}$ is the U.S. per capita quantity of fresh peaches produced in the South Atlantic region (in units of 0.45 
Table 1. Ordinary least squares coefficient estimates.

\begin{tabular}{|c|c|c|c|}
\hline Variable $^{\mathbf{z}}$ & & $\begin{array}{c}\text { Coefficient } \\
\text { estimate }\end{array}$ & $t$ value \\
\hline INTERCEPT & & 6.184 & 1.823 \\
\hline $\mathrm{Q}_{\mathrm{SA}}$ & (U.S. per capita quantity of South Atlantic fresh peaches) & -1.254 & $-2.859 y$ \\
\hline$P_{C A}$ & (real F.O.B. price of Calif. fresh peaches) & -0.077 & -0.154 \\
\hline$P_{P}$ & (real F.O.B. price of U.S. fresh plums) & 0.050 & 0.307 \\
\hline I & (real U.S. per capita disposable income) & 0.001 & 1.639 \\
\hline D1 & (intercept dummy, 1942-54) & 10.388 & 1.297 \\
\hline D3 & (intercept dummy, 1975-86) & 26.524 & $2.820^{y}$ \\
\hline $\mathrm{DS}_{1} \mathrm{Q}_{\mathbf{S A}}$ & $\left(Q_{\text {SA }}\right.$ slope dummy, 1942-54) & 0.342 & 0.673 \\
\hline $\mathrm{DS}_{3} \mathrm{Q}_{\mathrm{SA}}$ & $\left(Q_{\text {SA }}\right.$ slope dummy, 1975-86) & -0.542 & -0.564 \\
\hline $\mathrm{DS}_{1 \mathrm{P}_{\mathbf{C A}}}$ & ( $\mathrm{P}_{\mathrm{CA}}$ slope dummy, 1942-54) & 2.491 & $4.112^{\mathrm{y}}$ \\
\hline $\mathrm{DS}_{3} \mathrm{P}_{\mathrm{CA}}$ & ( $\mathrm{P}_{\mathrm{CA}}$ slope dummy, 1975-86) & 0.516 & 0.668 \\
\hline $\mathrm{DS}_{1} \mathrm{P}_{\mathbf{P}}$ & $\left(\mathrm{P}_{\mathbf{P}}\right.$ slope dummy, 1942-54) & -0.094 & -0.350 \\
\hline $\mathrm{DS}_{\mathrm{P}} \mathrm{P}_{\mathrm{P}}$ & $\left(\mathrm{P}_{\mathrm{P}}\right.$ slope dummy, 1975-86) & -0.031 & -0.118 \\
\hline DS1I & (I slope dummy, 1942-54) & -0.011 & $-2.574^{y}$ \\
\hline DS3I & (I slope dummy, 1975-86) & -0.008 & $-3.714^{y}$ \\
\hline$R^{2}$ & 0.85 & & \\
\hline $\mathrm{F}$ & 12.45 & & \\
\hline $\mathrm{N}$ & 45 & & \\
\hline
\end{tabular}

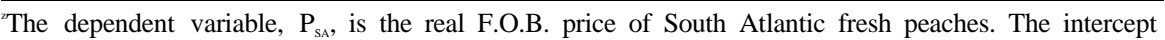
reflects the period $1955-74$.

y Corresponding coefficients are significant at $P=0.05$.

$\mathrm{kg}), \mathrm{P}_{\mathrm{CA}}$ is the deflated F.O.B. price of fresh peaches produced in California, $\mathrm{P}_{\mathrm{p}}$ is the deflated F.O.B. price of plums in the United States, and I is deflated U.S. per capita disposable income in dollars (U.S. Dept. of Agriculture, 1943-87; Dept. of Commerce, 1943-87). All prices are in cents per 0.45 $\mathrm{kg}$. An inverse demand function was used since, as with many agricultural commodities, the quantity of peaches offered for sale in any given year is the quantity produced, which, therefore, is predetermined (Houck, 1965). The price of fresh peaches produced in California and the price of plums were used to capture the potential substitution effects with South Atlantic fresh peaches. The price of plums was used instead of prices for other soft fruits based on preliminary analysis. United States per capita disposable income was used to measure the relationship between income and the demand for South Atlantic fresh peaches.

To investigate possible structural change in the demand for South Atlantic fresh peaches, recursive regression was employed to estimate Eq. [1] using annual data for the period of 1942 to 1986. Recursive least squares involves recalculation of the coefficients as each subsequent observation is added to a time-series data set (Harvey, 1981). The Chow test was used to test the null hypothesis that the coefficients of respective explanatory variables were equal between periods. Essentially, an F test is conducted to determine if coefficients for one data set, e.g., period 1, are the same as those for another data set, e.g., period 2. Further, a sequence of mutually independent Chow tests can be conducted from a series of one-step ahead prediction errors from recursive least squares (Harvey, 1981). Based on the results of recursive regression, dummy variables were added to the model, Eq. [1], to allow the intercept and slope coefficients to vary by identified time periods, employing ordinary least squares.

The structural change occurred between the periods 1942 to 19.54 and 1955 to 1974 and between the periods 1955 to 1974 and 1975 to 1986 . The critical $\mathrm{F}$ value for the Chow test, $P=0.05$, was $\approx 2.65$. The calculated $\mathrm{F}$ value for the first pair of periods was 17.4 and for the second pair it was 29.8. Thus, in both instances the null hypothesis was rejected. The results of ordinary least squares estimation of Eq. [1] with dummy variables, allowing the intercept and slope coefficients to vary according to the time periods just delineated, are presented in Table 1.

The coefficient signs for the variables contained in Eq. [1], as reflected in Table 1, were as expected or plausible except for the sign of the coefficient for $\mathrm{P}_{\mathrm{cA}}$ (real F.O.B. price of California fresh peaches), which was not significant. These coefficients are reflective of the designated base period, 1955-74 (period 2). The positive signs of the coefficients for the intercept dummy variables, D1 (1942-54 or period 1) and D3 (1975-86 or period 3), mirror a cyclical pattern in $\mathrm{P}_{\mathrm{sA}}$ (real F.O.B. price of South Atlantic fresh peaches) or change in demand such that $P_{S A}$ tended to be relatively lower in the base period. The lack of significance of the coefficients for $D_{S I Q}$ and $D S 3 Q_{\mathrm{sA}}$ (slope dummies for $\mathrm{Q}_{\mathrm{SA}}$ in periods 1 and 3 , respectively) indicated no real structural change in the price-quantity relationship for South Atlantic fresh peaches over time. The positive sign and significance of the coefficient for $\mathrm{DSIP}_{\mathrm{CA}}$ (slope dummy for $\mathrm{P}_{\mathrm{CA}}$ in period 1) indicates that South Atlantic and California fresh peaches were strong substitutes in the first period. The lack of significance of the coefficients for $\mathrm{P}_{\mathrm{CA}}$ and $\mathrm{DS} 3 \mathrm{P}_{\mathrm{CA}}$ (slope dummy for $P_{C A}$ in period 3) suggests that the substitution effect between South Atlantic and California fresh peaches has waned with time. Given the lack of significance of the coefficients for $\mathrm{P}_{\mathrm{P}}, \operatorname{DSIP}_{\mathrm{P}}$ (slope dummy for $\mathrm{P}_{\mathrm{P}}$

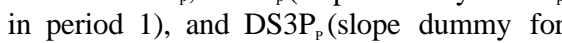
$P_{p}$, in period 3 ), the substitution effect from fresh U.S. plums was not evident in any period. Though the coefficient for I was not significant at $P=0.05$, the coefficients for
DS1I and DS3I (slope dummies for I in periods 1 and 3, respectively) were significant and negative. In period 1 , the real price of South Atlantic fresh peaches tended to be higher relative to the base period (period 2), while real U.S. per capita disposable income was relatively lower. In period 3, the same inverse price-income relationship manifested. However, in this case, the trend in real U.S. per capita income was markedly up, while the real price of South Atlantic fresh peaches reflected no such trend. In regard to trends for the other variables represented in the model, none of the price variables exhibited a long-run positive or negative pattern; however, $\mathrm{Q}_{\mathrm{sA}}$ (which is on a U.S. per capita basis) trended markedly downward, while no trend was detected for the total annual supply of South Atlantic fresh peaches.

The results of the analysis indicate that structural change in farm-gate demand has not occurred with respect to the price-quantity relationship for South Atlantic fresh peaches. The- substitution effect from California fresh peaches has diminished, while that of U.S. fresh plums remains insignificant. Though the apparent impact of disposable income on the demand for South Atlantic fresh peaches is negative, the relationship appears to be associative rather than causal. In the early years under study, relatively high real prices for South Atlantic peaches were associated with relatively low real U.S. per capita income, while in the later years of the analysis, relatively low real prices for South Atlantic peaches were associated with relatively high real U.S. per capita income. Moreover, the questionable negative impact from real U.S. per capita income is offset by an apparent increase in demand for South Atlantic fresh peaches, as reflected in the positive and significant coefficient for the dummy variable D3. The importance of this observation for the South Atlantic peach industry is that a rising real U.S. per capita income does not appear to cause a net decline in the demand for South Atlantic fresh peaches.

We conclude that the falling U.S. per capita consumption of South Atlantic fresh peaches does not appear to be due to any fundamental changes in the demand for South Atlantic fresh peaches as estimated in this study. However, the fall in the U.S. per capita consumption of South Atlantic fresh peaches is associated with an increase in the U.S. per capita consumption of a variety of fresh fruits. The implied prescription for the South Atlantic fresh peach industry is to pursue competitive measures that may increase the demand for South Atlantic fresh peaches. Examples of such measures may include promotion and advertising, uniform quality control standards, and cultivar development.

\section{Literature Cited}

Epperson, J.E. 1986. Consumption trends and prospects. In: J.G. Woodroof and B.S. Luh. (eds.). AVI Publishing, Westport, Conn.

Harvey, A.C. 1981. The econometric analysis of 
time series. Philip Allan Publishers Limited, oxford, U.K.

Houck, J.P. 1965. The relationship of direct price flexibilities to direct price elasticities. J. Farm Econ. 47:789-792.

McCurry, R.F. 1984. Peaches for sale. Peach Times. 29, 5:1-2.

Mizelle, W.O., Jr. 1984. The changing peach demand and its affect on prices. Georgia Coop. Ext. Ser. Special Rpt. 215.
Putnam, J.J. 1989. Food consumption, prices, and expenditures, 1966-1987. U.S. Dept. Agr. Econ. Res. Ser. Stat. Bul. 773.

Tomek, W.G. and K.L. Robinson. 1981. Agricultural product prices. 2nd ed. Cornell Univ. Press, Ithaca, N.Y.

U.S. Department of Agriculture. 1943-87. Agricultural statistics. U.S. Govt. Printing Office, Washington, D.C.
U.S. Department of Agriculture, Agricultural Marketing Service, Marketing News Branch. 1985-89. Fresh fruit and vegetable arrival totals for 23 cities. FVAS-3, Washington, D.C.

U.S. Department of Commerce. 1943-87. Statistical abstract of the United States. U.S. Govt. Printing Office, Washington, D.C.

Zind, T. 1991. Fresh trends ' 91 . The Packer Focus 1990-91. 97(54):38-39. 